\section{Fotofattig atlas for allmennpraktikarar}

Usatine RP et al, red.

The color atlas of family medicine

1095 s, tab, ill. New York, NY: The McGraw-Hill, 2008. Pris USD 100

ISBN 978-0-07-147464-1

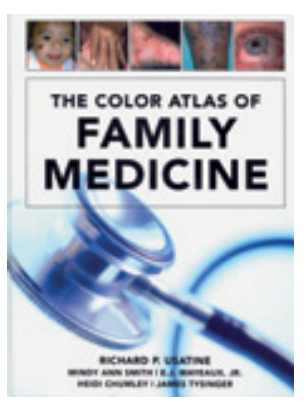

Dette har eg gledd meg til - eit medisinsk atlas som illustrerer det store mangfaldet av tilstandar allmennlegen møter, tilstandar som kan fotograferast og illustrerast. Det finst jo ei rekkje organ- og spesialitetspesifikke atlas, men konseptet med det allmennmedisinske som ramme er godt tenkt og velkommen. Tradisjonelle atlas tek ikkje omsyn til den allmennmedisinske epidemiologien, dei er ofte prega av bilete av langtkommen sjukdom og «monstrøse tilfelle frå Afrika». Det er gjerne vanskeleg å finne typiske, gode illustrasjonar til vanlege tilstandar eg møter på fastlegekontoret, spesielt utanom hudsjukdommane.

Atlaset har 1100 sider i storformat. Det første som slår meg, er kor liten del av alle trykkflatene som faktisk er foto og illustrasjonar. Dette framstår i staden som ei slags godt illustrert lærebok i amerikansk allmennmedisin, med mykje tekst om utgreiing, behandling, oppfølging og pasientinformasjon. Opplegget blir da frå norsk ståstad litt skuffande.

Hovudredaktøren er professor i allmennmedisin og dermatologi, og det forklarer truleg også at det er ei sterk slagside mot dei tradisjonelle hudsjukdommane. Der er 18 hovudkapittel med i alt 227 underkapittel, og kapittelet om huda står for $110 \mathrm{av}$ underkapitla. Der er ekstra god omtale av dermatoskopi og kolposkopi. Utanom huddelen er det stor variasjon i kva som er dekka, bilete av tilstandar som bursitt, struma og tådeformitetar fungerer godt, men det manglar tema som varicer, brokk, hemoroidar og mange andre tilstandar eg gjerne skulle sett bilete av. Kva tre sider om hoftebrot gjer i atlaset, er vanskeleg å forstå.

The color atlas of family medicine har diverre inga stor målgruppe i Noreg.

\section{Steinar Hunskår}

Seksjon for allmennmedisin

Institutt for samfunnsmedisinske fag

Universitetet i Bergen

\section{Rask smertelindring - for godt til å være sant?}

Benor DJ.

Seven minutes to natural pain release

WHEE for tapping your pain away. $251 \mathrm{~s}$, ill.

Fulton, CA: Energy Psychology Press, 2008.

Pris USD 18

ISBN 978-0-9819729-0-9

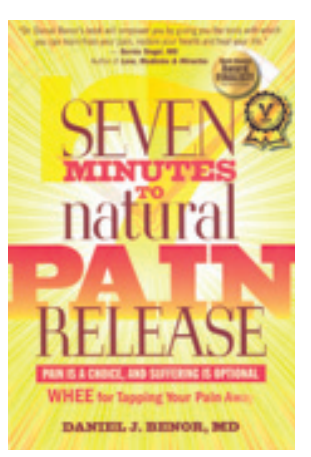

Psykiateren Daniel

J. Benor har

skrevet dette for pasienter og behandlere. Han beskriver en egenutviklet metode til lindring av smerter og angst - WHEE er forkortelse for «whole health easily and effectively». Man kan bli

litt skeptisk når han i innledningen skriver: «Welcome to the WHEE method for potent, quick, and easy pain relief. In opening this page in your life, you are entering a doorway to deep transformation on all levels of your being.» For psykologer lover han at WHEE blir et verdifullt tillegg til deres teraputiske armamentarium, andre helsearbeidere vil bli overrasket over hvor lett det er å lære denne «potente og raskt effektive metoden for selvhelbredelse».

Som bakgrunn gir han først en faglig korrekt, velskrevet, men forenklet fremstilling av smertens betydning som livsnødvendig overlevelsesfunksjon og omtaler faktorer som kan forsterke smerte. Mange psykologiske mekanismer kan forsterke de subjektive plagene ved langvarig smerte, og det er disse han mener man ved hjelp av hans metode kan påvirke. Han beskriver så i flere kapitler hvordan han utviklet metoden ut fra velkjente psykologiske teorier og behandlingsmetoder som bl.a. transaksjonsanalyse, autogen trening, autohypnose og «mindfulness». Seven minutes to natural pain release er utgitt i en serie med «Wholistic Healing Publications», forlaget er Energy Psychology Press i California.

Er dette seriøs medisin? Det er neppe «evidence based medicine». Forfatteren beskriver en rekke kasuistikker med godt resultat av behandlingen. Og eksperters meninger kan også være grunnlag for kunnskapsbasert medisin, men med svakest mulige evidensgrunnlag.

Dette synes å ligge i samme gate som bl.a. «tankefeltterapi». Kan hende mobiliserer denne og liknende metoder endogene tilhelende krefter, slik «lightening process» for kronisk utmattelsessyndrom tydeligvis kan gjøre? Jeg er ingen ekspert på slikt, men min hypotese er at behandlere som lykkes der tradisjonell medisin ikke har hatt virkning på pasienters subjektive plager, er slike som har uttalte empatievner og nok faglig innsikt, livserfaring, tid og «common sense» til å kunne hjelpe noen (men ikke alle) med subjektive psykologiske tilleggsproblemer. Og da er selve teknikken som brukes, det være seg «tapping», «hugging», terapeutiske samtaler, kan hende mindre viktig enn behandleren selv.

Med sin bakgrunn som psykiater og sine erfaringer med andre psykologiske teknikker har Benor evnet å gi en ryddig fremstilling av sine teorier og hvorfor metoden hans kan virke. Han siterer Hippokrates, som skal ha sagt: «Den gode legen behandler sykdommen, den virkelige store legen behandler pasienten som har sykdommen.»

Er man interessert $\mathrm{i} a ̊$ sette seg inn i enda en variant av psykologisk behandling av subjektive plager, er dette interessant nok. Alle som synes kontekstsensitive behandlingseffekter er tvilsomme saker, vil kan hende finne denne bokens innhold noe fantasifullt.

\section{Harald Breivik}

Det medisinske fakultet

Universitetet i Oslo

\section{Detaljert om diabetes på svensk}

Mulder $\mathrm{H}$.

\section{Diabetes mellitus}

Ett metabolt perspektiv på en växande folksjukdom. 177 s, tab, ill. Lund: Studentlitteratur, 2008. Pris SEK 223 ISBN 978-91-44-02081-5

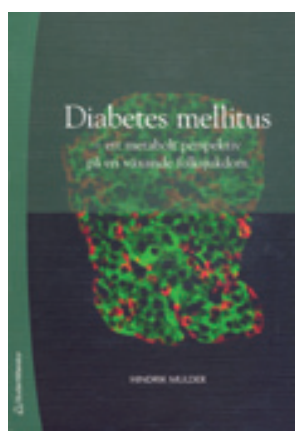

Forfatteren har undervist medisinstudenter ved Lunds universitet i mange år, og med denne utgivelsen henvender han seg i første rekke til disse, selv om den i forordet også anbefales for allmennpraktikere og diabetessyke-

pleiere. Innholdet i de 11 kapitlene er vesentlig en biologisk/biokjemisk tilnærming til diabetessykdommen. De normale prosesser og de forstyrrelser som ligger til grunn ved diabetes i cellenes og kroppens metabolisme, glukoseregulering og insulinets virkning omtales dels i betydelig detalj. Det er en kort historisk oversikt over hvordan forståelsen av diabetes har utviklet seg. Deretter følger kapitler om type 1- og type 2-diabetes og de øvrige, sjeldnere former for diabetes. De viktigste behandlingsprinsipper omtales og til sist de vanligste senkomplikasjonene. 
Diabetes mellitus er rikt illustrert med skisser og figurer, for det meste i svarthvitt, men det er noen få fargeplansjer på slutten. En god del tabeller og faktabokser bryter også opp teksten og gjør den lettere å lese, og stikkordregisteret er på hele 12 sider.

Jeg er i tvil om verdien av denne utgivelsen. Den inneholder mye oppdatert informasjon om diabetes for den som vil fordype seg i metabolske prosesser og forstå utviklingen av sykdommen. Men for dette formål finnes det store engelskspråklige verk som både er lettere å lese og overlegne i layout, bilde- og illustrasjonsmateriale. Denne er etter mitt syn for detaljert for den vanlige allmennpraktiker og diabetessykepleier, og den mangler for eksempel helt omtale av sosiale aspekter ved sykdommen og det å leve med diabetes. Behandlingsdelen er klart den svakeste. Den skjemmes også av noen unødvendige unøyaktigheter, for eksempel i definisjonene av nedsatt glukosetoleranse og HOMA-modellen for måling av insulinresistens.

Boken egner seg for medisinstudenter og leger med spesiell interesse for diabetes som vil fordype seg i de biologiske forstyrrelsene ved sykdommen og som gjerne vil lese en skandinavisk tekst. Den er trolig for detaljspekket for de fleste allmennpraktikere og diabetessykepleiere, som i sin daglige kliniske virksomhet sannsynligvis vil ha større nytte av å bruke fullversjonen av de nylig utgitte nasjonale kliniske retningslinjer for diabetes (Helsedirektoratet 2009) og eventuelt litteraturen som er referert i denne.

\section{Kåre I. Birkeland}

Avdeling for klinisk endokrinologi

Oslo universitetssykehus, Aker

\section{Nyttig om borreliainfeksjoner}

Lipsker D, Jaulhac B, red. Lyme borreliosis

Biological and clinical aspects. 212 s, tab, ill. Basel: Karger, 2009. Pris CHF 215

ISBN 978-3-8055-9114-0

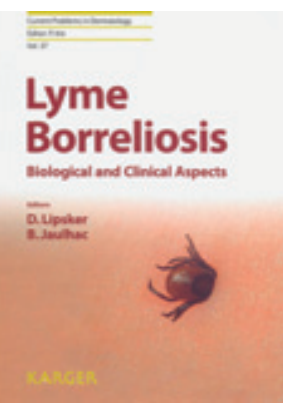

Lyme-borreliose er forbundet med mye usikkerhet, og det er derfor stort behov for samlet aktuell kunnskap om denne tilstanden. Lipsker \& Jaulhacs nye utgivelse kommer i en dermatologiserie, men målgruppen

er alle er som er involvert i diagnostikk og behandling av pasienter med borreliose ikke bare hudleger.
Første del består av oversiktskapitler om epidemiologi, kliniske manifestasjoner, diagnostikk og behandling. Det er også et kapittel om andre flåttbårne sykdommer. Europeiske eksperter har skrevet disse oversiktskapitlene, og vi får grundig og detaljert innføring i de ulike temaene. Både kliniske og biologiske aspekter dekkes på en fin måte. Systematikken er fin, layouten tiltalende og illustrasjonene informative, men en oppsummering i slutten av hvert kapittel savnes.

I siste del drøftes aktuelle spørsmål. De er relevante og pirrer nysgjerrigheten. Hva gjør man med et flåttbitt? Når skal man bestille Western blot, og hvordan skal svaret tolkes? Er serologiske kontrollprøver nyttig ved kutan borreliose? Hvordan behandle flåttbitt og borreliose hos gravide? Hva gjør man med persisterende plager etter adekvat antibiotikabehandlet borreliose? Når er spinalpunksjon indisert ved Lyme-sykdom? Lyme borreliosis gir gode og veldokumenterte svar på disse spørsmålene, men i noen tilfeller kunne det kommet klarere frem hva som er kontroversielt, og hvorfor.

Referanselisten er lang og relevant, men de nyeste publikasjonene mangler naturlig nok.

Alt $i$ alt er dette en svært nyttig utgivelse for den som vil skaffe seg en oversikt over den mystiske sykdommen Lyme-borreliose. Den anbefales for både allmennpraktikere og spesialister.

\section{Unn Ljøstad}

Nevrologisk avdeling

Sørlandet sykehus

Kristiansand

\section{Råd for den som ikke vil bli lurt}

Nordhelle G.

Manipulasjon

Forståelse og håndtering. 188 s, ill.

Oslo: Gyldendal Akademisk, 2009. Pris NOK 335 ISBN 978-82-05-39072-0

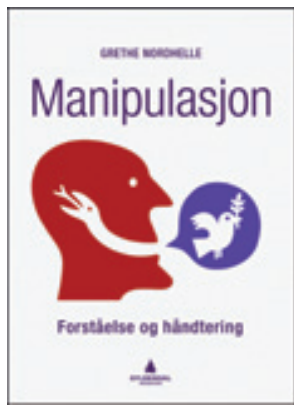

Denne utgivelsen inngår i en tradisjon av psykologisk forståelses- og selvhjelpslitteratur som bygger mer på forfatterens praktiske erfaringer enn på skarpsindige begrepsanalyser og empirisk forskning. Nord-

helle er psykolog og advokat med lang erfaring innen konflikthåndtering og megling, som hun har skrevet om tidligere. Ifølge vaskeseddelen henvender hun seg til fag- personer, inklusive leger, som arbeider med mennesker. Hensikten er å gi en dypere forståelse av manipulasjon, for dermed å hjelpe dem til å identifisere og avsløre fenomenet. Det er flere grunner til at denne målsettingen ikke nås.

Forfatteren slår fast: «Manipulasjon er en bevisst falsk/usaklig presentasjon, som på en skjult måte og med hensikt, får andre til å gjøre noe fordelaktig for manipulator, som de ikke er klar over at de ellers ikke ville gjøre.» Definisjoner med doble nektelser er alltid besværlige. I kapitlet om fenomenet greier ikke forfatteren å nå frem til klarhet om hva manipulasjon egentlig er - spillteknikk, kommunikasjonsstrategi, mestringsmåte, forsvarsmekanisme, vane eller alt sammen? Det er selvfølgelig viktig å skille manipulasjon fra tilgrensende fenomener som påvirkning, overtalelse og trusler, men også her er fremstillingen preget av uklarheter og omtrentligheter. Forholdet mellom manipulasjon, uansett hva det er, og psykopati, som er en psykisk lidelse, fremstilles direkte feilaktig. Forfatteren beskriver også en utvikling fra sporadisk manipulasjon via vanemessig manipulasjon, manipulasjonskarakter, kronisk manipulasjon, rigid manipulasjonsmønster til personlighetsforstyrrelse som det ikke finnes noen som helst empirisk dekning for.

I teksten er det mange eksempler fra hverdagslivet, familielivet og jusen. Det er egne kapitler om manipulasjon av barn, særlig knyttet til samlivsbrudd, og manipulasjon innen religiøse organisasjoner og sekter. Dette er fortjenstfullt, men mange av eksemplene oppfyller ikke den definisjonen av manipulasjon som forfatteren legger til grunn.

Kapitlet om håndtering av manipulasjon er det beste. Her er det mange forslag til strategier for å avsløre og stoppe det. Jeg savner forfatterens forklaring på hvordan personer som har vært kuet og lurt av manipulerende nærstående gjennom lang tid, skal få styrke og selvtillit til å endre sin uhensiktsmessige kommunikasjonsform.

Jeg manipulerer altså ikke leserne av anmeldelsen når jeg påstår at Manipulasjon ikke oppfyller sin målsetting. Spørsmålet er om forlaget og forfatteren manipulerer oss. Forsiden er like enkel som genial et mannshode med en slange til munn og en fredsdue i snakkeboblen. Det kan få oss til å tro at innholdet er like godt og at boken bør kjøpes, men der blir vi manipulert!

\section{Alv A. Dahl}

Kreftklinikken

Radiumhospitalet

Oslo universitetssykehus, Rikshospitalet 